\title{
Effect of Foliar Fungicides on Late-season Anthracnose Stem Blight on Soybean
}

\begin{abstract}
Nathan R. C. Bestor, Alison E. Robertson, and Daren S. Mueller, Department of Plant Pathology and Microbiology, Iowa State
\end{abstract} University, 351 Bessey Hall, Ames 50011

Accepted 7 July 2014. Publication 14 August 2014.

\section{ABSTRACT}

Bestor, N. R.C., Robertson, A. E., and Mueller, D. S. 2014. Effect of foliar fungicides on late-season anthracnose stem blight on soybean. Plant Health Progress doi:10.1094/PHP-RS-14-0013.

Anthracnose stem blight, caused by Colletotrichum truncatum, is responsible for soybean (Glycine max) yield losses in subtropical and tropical growing regions. There are inadequate data regarding the effect of anthracnose stem blight on yield in Iowa, and it is unknown if fungicide application can manage this disease. Field studies were conducted from 2008 to 2010 to determine the effect of fungicide application timing on late-season development of this disease. We also

\section{INTRODUCTION}

Anthracnose stem blight (ASB) is an important disease of soybean (Glycine max (L.) Merr.) in commercial growing regions throughout the world and in the United States $(12,17)$. In Iowa, the disease is primarily caused by Colletotrichum truncatum (Schwein), but the disease can also be caused by other Colletotrichum species $(7,9)$. Soybean yield loss caused by this disease has been documented in tropical or subtropical environments $(1,2,9,17)$. While yield losses as high as $25 \%$ have been reported in the southern United States (2), the disease has not historically impacted soybean yield in the north central United States.

In Iowa, disease symptoms and signs typically only occur as the soybean crop begins to senesce. Most often irregular black lesions are observed on the main stem and pods. Lesions often coalesce and can cover a large portion of the stem. Lesions on soybean pods may lead to seed infection that can result in plant infection the following year. Fungal fruiting structures, called acervuli, form in lesions and look like small, dark spots. Under magnification these spots appear spiny. Anthracnose stem blight symptoms on soybean also may occur during early reproductive growth stages as reddening of leaf veins at the top of the plant followed by necrosis of the leaf lamina. This results in a characteristic "shepherds crook," which is a downward turning of necrotic leaves and petioles at the top of the plant. These symptoms are less common in Iowa than elsewhere.

Colletotrichum truncatum can overwinter in infected seed or infested plant residue, and some isolates can survive as microsclerotia in soil for up to four years (11). Cultural control measures for ASB include crop rotation and tillage, although crop rotation has limitations because of the broad host range of Colletotrichum spp. This host range includes several weeds

Corresponding author: Daren Mueller. Email: dsmuelle@iastate.edu

doi:10.1094/PHP-RS-14-0013

(C) 2014 The American Phytopathological Society investigated the effect of anthracnose stem blight on yield and specific yield components. Fungicides reduced late-season symptom development when compared to the untreated control; however, there were no differences in yield and yield components. While foliar fungicides can reduce late-season disease development, anthracnose stem blight typically should not affect crop management decisions involving use of foliar fungicides on soybean in Iowa. common in soybean fields that can serve as alternative hosts (7). Tillage may not be a viable management option for all farmers, especially those who practice soil conservation tillage practices. The use of fungicides can be effective $(1,2)$, and various classes of fungicides, including strobilurins (quinone outside inhibitors) and triazoles (demethylation inhibitors), are labeled in the United States for managing this disease.

Foliar fungicides have increasingly been applied to commercial soybeans (4). Initially this increase in foliar fungicide use was related to the introduction of Phakopspora pachyrhizi Syd and P. Syd., which causes soybean rust $(6,10,13,14)$. Today, in Iowa and other Midwestern states, fungicides are used to control numerous endemic diseases. High soybean grain prices have also contributed to increased fungicide use. As grain prices increase, the return on investment of a fungicide application increases, thus even small increases in yield may be cost effective. Consequently, fungicide applications have become a more common input in crop management than in previous years. Farmers and agronomists in Iowa have reported fewer ASB symptoms at harvest on soybean crops that have been sprayed with foliar fungicides.

Consequently, there have been questions regarding the effect of foliar fungicide applications on ASB and grain yield. The objectives of this research were to evaluate: (i) the effect of foliar fungicides applied at different growth stages on ASB severity, and (ii) the impact of late-season ASB development on soybean grain yield.

\section{MANAGEMENT OF ANTHRACNOSE STEM BLIGHT WITH FOLIAR FUNGICIDES}

Experiments were conducted at Iowa State University research farms. Field trials were conducted at a total of 11 locations in 2008, 2009, and 2010. Locations, soybean variety, and field activities are summarized in Table 1. A randomized complete block design was used with five or six replications and plots were 35 to $50 \mathrm{ft}$ long and 4 to 6 rows wide (30-inch row spacing) depending on the location. Headline (pyraclostrobin, 6 oz/acre; 


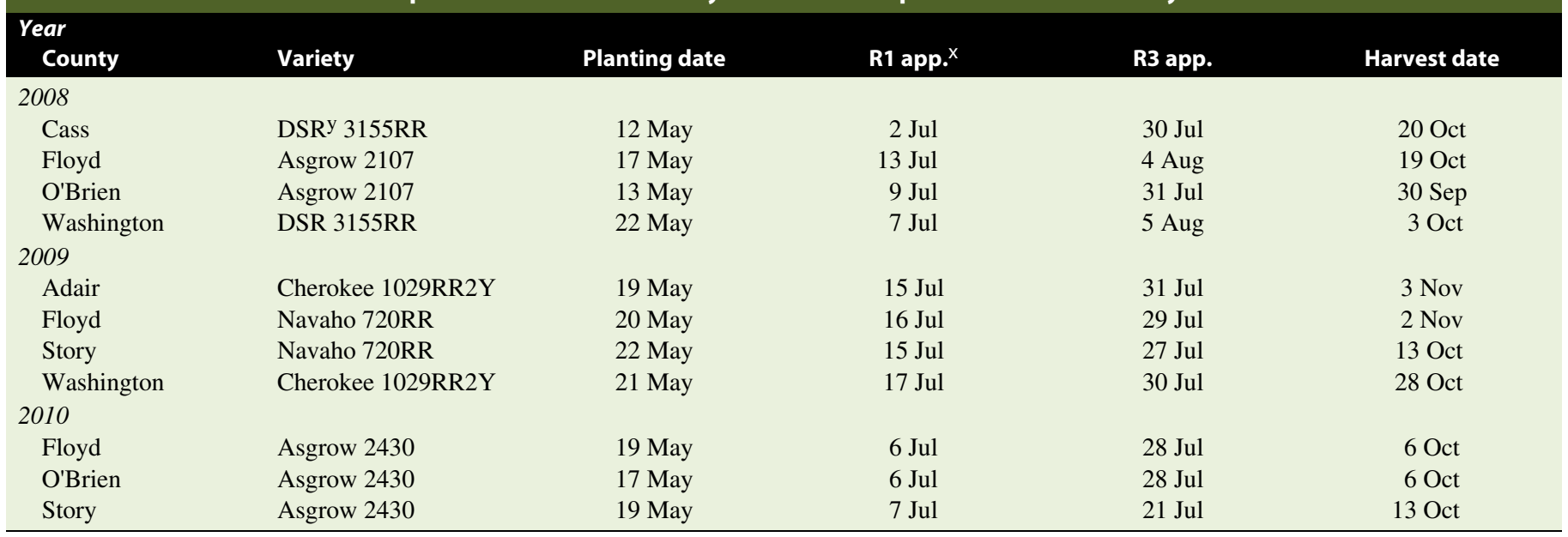

${ }^{\mathrm{x}} \mathrm{R} 1$ and R3 applications were based on the growth stage of soybean. Growth stage R1 is the beginning of flowering and growth stage R3 is the beginning of pod set (5).

${ }^{\mathrm{y}}$ DSR = Dairyland Seed Research

BASF, Research Triangle Park, NC) and Stratego YLD (trifloxystrobin + prothioconazole, 6 oz/acre; Bayer CropScience, Research Triangle Park, NC) were applied using a $\mathrm{CO}_{2}$-powered backpack sprayer system (R\&D Sprayers, Opelousas, LA) calibrated to spray $20 \mathrm{gal} /$ acre either at growth stage R1 (beginning flowering) or R3 (beginning pod set) (5). Anthracnose stem blight severity was determined by estimating the percentage of the main stem and pods covered by lesions at full maturity (R8) (5) on 20 consecutive plants in one of the middle two rows of each plot. The starting point for these 20 plants was arbitrarily selected. Plot combines were used to harvest the middle two rows of each plot, and yield data were standardized to $13 \%$ moisture for comparison. Standard herbicide practices were used at each location as needed.

Mean anthracnose severity and yield were calculated and analyzed using the mixed model procedure in SAS (SAS Institute Inc., Cary, NC). Data were analyzed separately for each fungicide since Headline was evaluated at seven locations and Stratego YLD was evaluated at all 11 locations. Locations were combined for analysis, although the location $\times$ treatment interaction was significant for ASB for both fungicides (Headline, $P=0.003$ and Stratego YLD, $P<0.001)$. However, for each fungicide there was only one location that created this significant interaction.

Headline treatments and the untreated control were not significantly different $(P=0.661)$ at the Nashua location in 2009, and the Stratego YLD treatments and untreated control were not significantly different $(P=0.322)$ in Nashua in 2010. The other 6 locations for Headline and 10 locations for Stratego YLD showed significant differences between the untreated control and both fungicide timings. In each case, disease severity on untreated plants was greater than plants with the R1 application, and the disease severity on plants with the R1 application had more disease than plants with the R3 application. There was not a significant location $\times$ treatment interaction for yield (Headline, $P=0.834$ and Stratego YLD, $P=0.696$ ).

Applications of fungicides were effective in controlling disease in all years, despite mean severity fluctuating greatly year-to-year. Across all years and locations Headline applications at R1 reduced ASB $41.5 \%$ when compared to the untreated control (Table 2). Headline applied at R3 reduced disease $62.4 \%$. Stratego YLD reduced ASB severity 46.3 and $60.8 \%$ when applied at R1 or R3, respectively (Table 2).
There were significant $(P<0.001)$ increases in yield with both R1 and R3 applications of Headline compared to the untreated control (Table 2). Also, there was a significant $(P<0.001)$ increase in yield following an R3 application of Stratego YLD, but not with an R1 application, when either were compared to the untreated control (Table 2). There was very little foliar disease at most site years (data not shown). However, two site years, Story County (2009) and Story County (2010), had enough foliar disease to affect yield. While fungicide applications generally decreased ASB and increased yield, there was not a significant relationship between disease severity and yield at any location $(P>0.05)$, except at Story County in $2010(P=0.007)$.

\begin{tabular}{|c|c|c|}
\hline \multicolumn{3}{|c|}{ TABL } \\
\hline \multicolumn{3}{|c|}{ Headline (7 locations) } \\
\hline Timing $^{\mathrm{w}}$ & ASB severity ${ }^{x}$ & Yieldy \\
\hline $\mathrm{R} 1$ & $15.9 \mathrm{~b}^{\mathrm{z}}$ & $59.9 \mathrm{a}$ \\
\hline R3 & $10.2 \mathrm{c}$ & $61.6 \mathrm{a}$ \\
\hline Untreated control & $27.2 \mathrm{a}$ & $57.5 \mathrm{~b}$ \\
\hline$P$ value & $<0.001$ & $<0.001$ \\
\hline \multicolumn{3}{|c|}{ Stratego YLD (11 locations) } \\
\hline Timing ${ }^{w}$ & ASB severity ${ }^{x}$ & Yieldy \\
\hline $\mathrm{R} 1$ & $11.2 \mathrm{~b}$ & $57.2 \mathrm{~b}$ \\
\hline R3 & $8.2 \mathrm{c}$ & $58.7 \mathrm{a}$ \\
\hline Untreated control & $20.9 \mathrm{a}$ & $55.6 \mathrm{bc}$ \\
\hline$P$ value & $<0.001$ & $<0.001$ \\
\hline $\begin{array}{l}\text { w Fungicide applic } \\
\text { Growth stage R1 } \\
\text { is the beginning } \\
\text { x Mean percent an } \\
20 \text { consecutive s } \\
\text { y Yield in bushels } \\
\text { z Treatments with } \\
\text { different accordi }\end{array}$ & $\begin{array}{l}\text { re based on the g } \\
\text { ginning of flowe } \\
(5) \text {. } \\
\text { stem blight seve } \\
\text { ems per plot. } \\
\text { tandardized at } 1 . \\
\text { letter are not con } \\
\text { SD test }(P>0.0\end{array}$ & $\begin{array}{l}\text { e of soybean. } \\
\text { owth stage R3 } \\
\text { y estimated on } \\
\text { nificantly }\end{array}$ \\
\hline
\end{tabular}




\section{ANTHRACNOSE STEM BLIGHT AND YIELD LOSS}

From each field location in each year, 50 to 100 plants in untreated plots were hand harvested. Plants were chosen to give an even gradient from low to high ASB severity. These plants were not representative of the overall disease severity and were not chosen at random. Each plant was assessed for ASB severity as a percentage of lesions covering the stem and pods. The number of pods per plant, seeds per pod, and seed weight were determined for each plant. There was no significant interaction between the yield components, fungicides, and locations so data were combined across all sites. The relationship between yield components and anthracnose stem blight severity was calculated using the correlation procedure in SAS.

While soybean plants were purposely selected to represent a range of ASB severity in each field, mean severity still varied between locations. For example, mean severity was 56 and $9.9 \%$ in 2009 in Floyd and Adair counties, respectively (Table 3). A summary of average severity and yield components collected for each year and location can be found in Table 3. Late-season anthracnose stem blight did not have a significant $(P>0.05)$ correlation with any of the yield component data.

\section{CONCLUSIONS}

Fungicide applications generally decreased ASB and increased yield; however, a significant relationship was found between ASB severity and yield at only one of the 11 site years. Our results are consistent with a report (16) from Indiana in which a reduction in late-season stem symptoms did not result in a yield response. Our results differ from those of Backman et al. $(1,2)$ who discovered that anthracnose stem blight did reduce soybean yields; however, Backman's study was done in the southern United States, where infection was estimated to occur during early reproductive stages. There has been limited research on the effect of anthracnose stem blight on yield, and apart from the report from Indiana, there are no other reports of late-season symptomology and its effect on yield. Early season symptoms of anthracnose stem blight are not common in Iowa, and the rare occurrence of early season anthracnose stem blight symptoms in Iowa has not been explored. It is possible that early season environmental conditions are not conducive for infection and/or early disease development. Disease development is favored by periods of frequent rain and temperatures above $77^{\circ} \mathrm{F}(3,8)$.

Since we observed no relationship between disease severity and yield response in the fungicide studies, we assume in some cases where there was a yield response to the application of fungicides that other diseases, such as frogeye leaf spot (Cercopsora sojina Hara) were influencing yield response. This was the situation in Story County in 2010. There was no relationship between disease severity and any yield component.

Reduction of ASB during very late reproductive stages did not affect yield. Soybean yield is mostly determined between growth stages R1 (beginning flowering) and R6 (full seed), and consequently stressors have the most impact when they occur during those stages, especially between R3 (beginning pod set) and R6 when seed fill is occurring (15). In our study, ASB symptoms did not appear until after growth stages R6 or R7 when the soybeans were approaching maturity and had no effect on yield even when fungicides controlled the disease. Since applications of a fungicide at R3 reduced disease we suggest anthracnose infection occurred at R3 to R4.

From this study, Iowa farmers should not have to consider lateseason ASB when developing a crop management strategy. The application of fungicides should only be considered when trying to manage diseases that reduce yield potential. In Iowa and other north central states, such diseases may include Septoria brown spot (Septoria glycines Hemmi) and frogeye leaf spot, and both have the potential to reduce soybean yields in the Midwest $(4,17)$. Consequently, an application of fungicide may be necessary in some years to protect yield from fungal foliar diseases. Although we found late-season development of anthracnose stem blight did not impact yield in this study in Iowa, given the proper environmental conditions for disease development, this disease can possibly reduce soybean yield elsewhere $(1,2,12,17)$.

\section{ACKNOWLEDGMENTS}

We thank Iowa State University research farm superintendents and undergraduate students for their assistance with field operations and data collection. Research was funded through soybean checkoff and the Iowa Soybean Association.

Mean pods per plant, seeds per pod, $\mathbf{1 0 0}$ seed weight (g), and percent anthracnose stem blight severity
of soybean at various locations in lowa in 2008, 2009, and 2010.

${ }^{\mathrm{x}}$ Regression analysis between mean percent anthracnose stem blight severity and yield components yielded either no significant relationship and/or slopes were nearly zero.

y Average 100 seed weight data in 2009 was not measured prior to eliminating seed. 


\section{LITERATURE CITED}

1. Backman, P. A., Rodriguez-Kabana, R., Hammond, J. M., and Thurlow, D. L. 1979. Cultivar, environment, and fungicide effects on foliar disease losses in soybeans. Phytopathology 69:562-564.

2. Backman, P. A., Williams, J. C., and Crawford, M. A. 1982. Yield losses in soybeans from anthracnose caused by Colletotrichum truncatum. Plant Dis. 66:1032-1034.

3. Chongo, G., and Bernier, C. C. 2000. Effects of host, inoculum concentration, wetness duration, growth stage, and temperature on anthracnose of lentil. Plant Dis. 84:544-548.

4. Cruz, C. D., Mills, D., Paul, P. A., and Dorrance, A. E. 2010. Impact of brown spot caused by Septoria glycines on soybean in Ohio. Plant Dis. 94:820-826.

5. Fehr, W. R., and Caviness, C. E. 1977. Stages of soybean development. Spec. Rep. 80. Iowa State University, Ames

6. Galloway, J. 2008. Effective management of soyabean rust and frogeye leaf spot using a mixture of flusilazole and carbendazim. Crop Prot. 27:566-571.

7. Hartman, G. L., Manandhar, J. B., and Sinclair, J. B. 1986. Incidence of Colletortrichum spp. on soybeans and weeds in Illinois and pathogenicity of Colletotrichum truncatum. Plant Dis. 70:780-782.

8. Hartman, G. L., Sinclair, J. B., and Rupe, J. C. 1999. Compendium of Soybean Diseases, 4th ed. American Phytopathological Society, St. Paul, MN.

9. Hepperly, P. R., Mignucci, J. S., Sinclair, J. B., and Mendoza, J. B. 1983. Soybean anthracnose and its seed assay in Puerto Rico. Seed Sci. Technol. 11:371-380.
10. Kemerait, R. C., Sconyers, L. E., Jost, P. H., Kichler, J., and Clark, J. 2006. Managing Asian soybean rust in Georgia with fungicides. Phytopathology 96:S186.

11. Khan, M., and Sinclair, J. B. 1992. Pathogenicity of sclerotia- and nonsclerotia-forming isolates of Colletotrichum truncatum on soybean plants and roots. Phytopathology 82:314-319.

12. Koenning, S. R., and Wrather, J. A. 2010. Suppression of soybean yield potential in the continental United States by plant diseases from 2006 to 2009. Plant Health Progress doi:10.1094/PHP-2010-1122-01-RS.

13. Miles, M. R., Levy, C., Morel, W., Mueller, T., Steinlage, T., van Rij, N., Frederick, R. D., and Hartman, G. L. 2007. International fungicide efficacy trials for the management of soybean rust. Plant Dis. 91:14501458.

14. Mueller, T. A., Miles, M. R., Morel, W., Morois, J. J., Wright, D. L., Kemerait, R. C., Levy, C., and Hartman, G. L. 2009. Effect of fungicide and timing of application on soybean rust severity and yield. Plant Dis. 93:242-248.

15. Pedersen, P. 2004. Soybean growth and development. Ext. Publ. PM1945. Iowa State University, Ames.

16. Wise, K., and Buechley, G. 2010. Evaluation of foliar fungicides for soybean disease management in Indiana, 2009. Plant Dis. Man. Rep. 4:FC088. doi: 10.1094/PDMR04.

17. Wrather, A., Shannon, G., Balardin, R., Carregal, L., Escobar, R., Gupta, G. K., Ma, Z., Morel, W., Ploper, D., and Tenuta, A. 2010. Effect of diseases on soybean yield in the top eight producing countries in 2006. Plant Health Progress doi:10.1094/PHP-2010-0125-01-RS. 